Section Editors

David C. Spencer, MD

Steven Karceski, MD

Murray G. Brown, PhD

\title{
Cost of disease-modifying therapies for multiple sclerosis
}

In their article "The cost of multiple sclerosis drugs in the US and the pharmaceutical industry: Too big to fail?" Hartung and colleagues ${ }^{1}$ describe "alarming" increases in US prices of disease-modifying therapies (DMTs) for persons with relapsing-onset multiple sclerosis (MS). They looked at drug pricing from 1993 to 2013. This review summarizes their findings and discusses the relevance for those with MS.

WHAT ARE MS "DISEASE-MODIFYING THERAPIES"? DMTs are drugs that alter the natural course of MS. They reduce the frequency and severity of attacks, reduce new brain lesions, and slow the development of disability. They are part of a group of medicines called "biologic drugs." DMTs are more effective when prescribed soon after onset of MS symptoms. People with MS usually take them for many years. The first DMTs were marketed in the US in the early 1990s. Their prices ranged from $\$ 9,000-\$ 12,000$ per patient per year. Newer and more effective DMTs have higher price tags. More are on their way.

WHAT DID THE AUTHORS STUDY? Few patients can pay for expensive DMTs from their own pockets for a long time. Most patients pay through private health care insurance premiums, insurance copayments, or taxes. Hartung and colleagues studied DMT prices paid by 2 US public health insurance programs, Medicaid and the Veterans Administration (VA), and also by public insurance programs in Canada (Ontario), Australia, and the United Kingdom. DMT prices paid by private health insurance companies and by patients themselves were not compared because they were not available.

WHAT DID THE AUTHORS FIND? DMT prices paid by Medicaid increased much faster than US consumer prices and other drug prices. By 2014, prices paid by Medicaid for first-generation DMTs had increased from $\$ 9,000-\$ 12,000$ to $\$ 60,000$ per patient per year. DMT prices paid by the VA started lower and increased slower than those paid by Medicaid. DMT prices paid in Canada (Ontario), Australia, and the United Kingdom are much lower than Medicaid prices. These DMT price increases are shown in figures 1 and $2 .{ }^{1}$
WHAT IS STILL UNKNOWN? Some of this study's findings are puzzling. For example, why did firstgeneration MS DMT prices increase much faster than similar biologic drugs for other conditions? Often when a drug's patent expires, a generic medication equivalent becomes available at much lower cost. Why did this not happen with DMTs? Methods for producing biologic drugs changed little from 1994 to 2013. This explains in part why firstgeneration DMT prices did not fall after their patent protection period expired: generic DMTs can't be produced much cheaper.

Why did prices of first-generation MS DMTs increase so much faster than prices for other biologic drugs? Why did MS patients insured through Medicaid continue to receive DMTs despite huge price increases from 1994 to 2013? Why are prices paid by the VA much lower and more stable than prices paid by Medicaid for the same DMTs? Why are DMT prices paid by Medicaid 7 times higher than prices paid in Canada (Ontario), Australia, and the United Kingdom?

One answer is obvious-international drug companies increased MS DMT prices to increase profits. However, it is not obvious why drug companies were able to increase prices paid by Medicaid but not by the VA or public insurers in other countries.

WHY IS THE STUDY OF DMT PRICE INCREASES IMPORTANT? Higher prices will affect those with MS or other diseases, neurologists and other health care providers, private and public sector health insurers, and taxpayers. The economic "law of supply and demand" is that demand falls (eventually) in response to price increases. Given DMT price increases from 1994 to 2013, Medicaid purchases of DMTs should have decreased, not increased, during this period.

WHAT IS THE MARKET COMPETITION? The full story is not clear, but the authors' evidence suggests that US law restricts economic competition between drug sellers and Medicaid buyers. The economic playing field is not level. Even with large price increases, Medicaid continues to buy DMTs for patients with MS who are eligible for insurance coverage. This is because US law prevents Medicaid managers from negotiating lower prices. In contrast, the VA is 


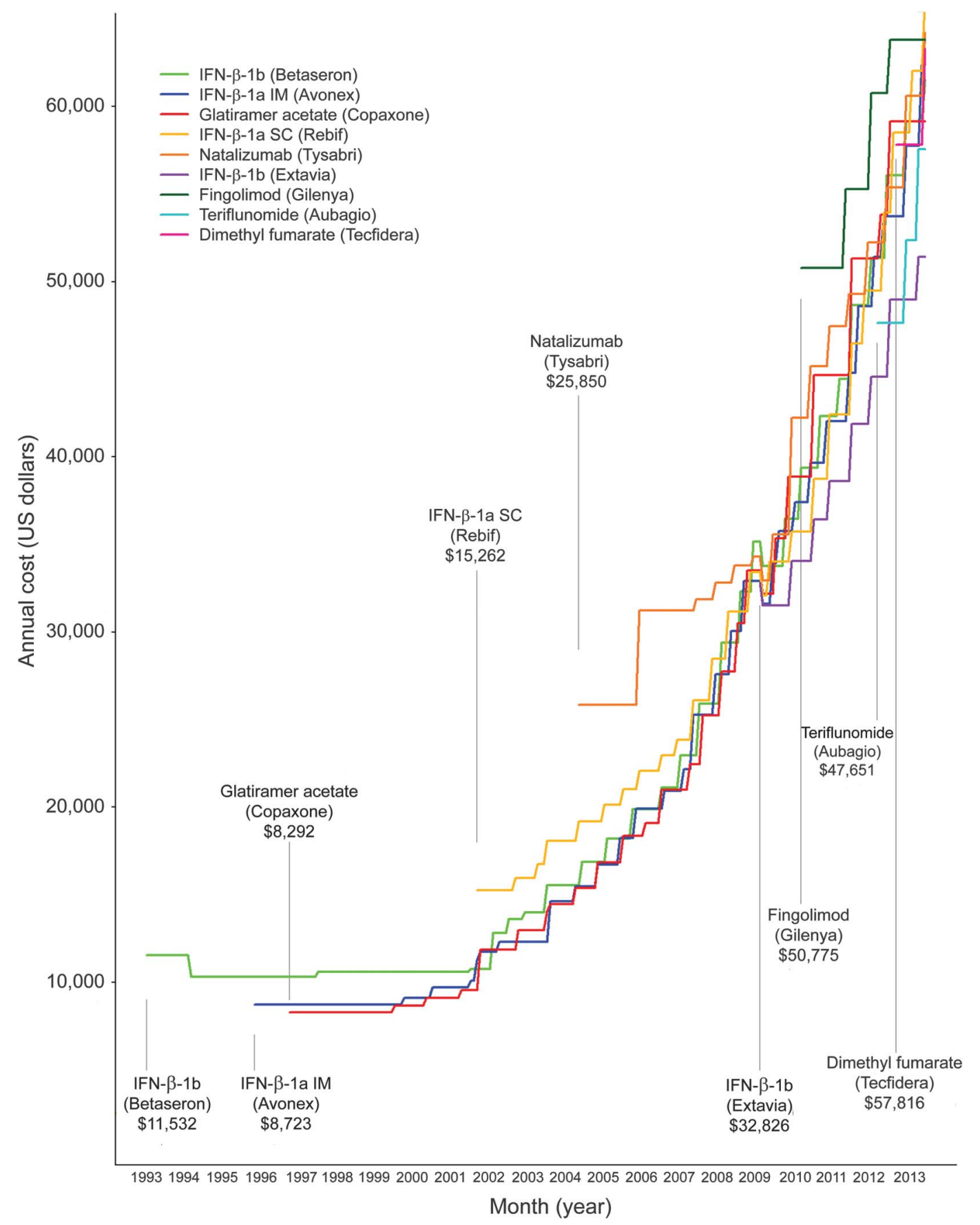

Annual costs estimated from average wholesale prices (AWP), or wholesale acquisition costs if AWP not reported, and discounted 12\%; IFN = interferon; IM = intramuscular; SC = subcutaneous. From Hartung DM, Bourdette DN, Ahmed SM, Whitham RH. The cost of multiple sclerosis drugs in the US and the pharmaceutical industry: Too big to fail? Neurology 2015;84:2185-2192. ${ }^{1}$

permitted to negotiate lower prices. Restricted competition benefits drug company shareholders and executives. Citizens, as patients and taxpayers, are the losers.

In 2013, Medicaid prices for first-generation DMTs were 7 times higher than prices paid in Canada (Ontario), Australia, and the United Kingdom.
These countries encourage competition between private sector sellers and public sector buyers. They also compare effectiveness and look at cost-effectiveness when spending tax dollars.

The drug companies' ability to increase MS DMT prices for Medicaid but not for other public sector health care insurers seems to reflect US law that 


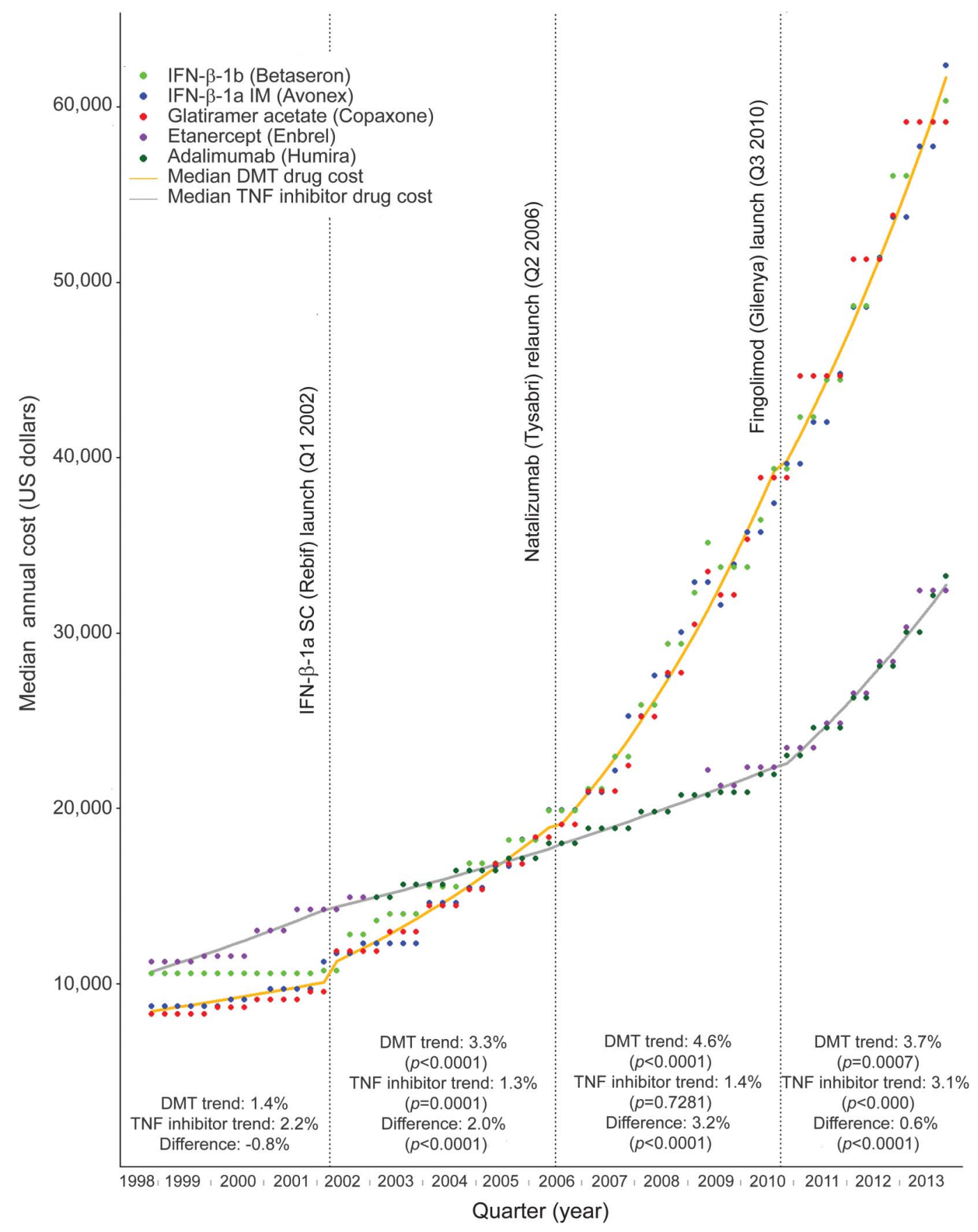

Disease-modifying therapies (DMTs) are interferon (IFN)- $\beta-1 b$, IFN- $\beta-1 a$ intramuscular (IM), glatiramer acetate, and tumor necrosis factor (TNF) inhibitors etanercept and adalimumab. Trends are \% change in median annual cost per quarter. With the exception of the first (baseline) period, $p$ values reflect changes in trend from one period to the next. Complete model results are reported in appendix e-1. SC = subcutaneous. From Hartung DM, Bourdette DN, Ahmed SM, Whitham RH. The cost of multiple sclerosis drugs in the US and the pharmaceutical industry: Too big to fail? Neurology 2015;84:2185-2192. ${ }^{1}$

restricts competitive behavior by Medicaid. More competition between private sector sellers and public sector buyers benefits consumers of public sector goods and services.

Drug company executives seem to be betting that Congress will not remove restrictions on competitive behavior by Medicaid managers and that nobody will be held accountable for very aggressive pricing decisions. Who knows what Congress will or will not do? But if the bet is lost, drug company shareholders will be the losers, not drug company executives. ${ }^{2}$

COST-EFFECTIVENESS REVISITED In the 1990s, patients with MS joined with neurologists and drug 
companies to lobby for public sector insurance coverage of expensive MS DMTs. They succeeded in the United States and in other developed countries but only after heated debates about the effectiveness and cost-effectiveness of MS DMTs under "real world" conditions. Given the size of DMT price increases paid by Medicaid from 1994 to 2013, DMTs would no longer pass cost-effectiveness tests applied by Medicaid or other insurers. This is relevant for patients. Access to effective but expensive drugs through private sector or public sector insurers will eventually be restricted in various ways when drugs no longer pass "cost-effectiveness" tests because their prices increased too much.

A NATIONAL CONVERSATION Hartung and colleagues urge neurologists to start a national conversation about "alarming" increases in MS drug prices.
This debate may challenge Congress to establish competitive markets for all dealings between private sector sellers and public sector buyers. Patients and clinicians would benefit from continued access to effective therapies. Drug company shareholders would earn returns on investment that reflect the risks associated with developing and marketing cost-effective therapies. Finally, taxpayers would benefit from greater "value per tax dollar."

\section{REFERENCES}

1. Hartung DM, Bourdette DN, Ahmed SM, Whitham RH. The cost of multiple sclerosis drugs in the US and the pharmaceutical industry: too big to fail? Neurology 2015; 84:2185-2192.

2. Morgenson G. Ways to put the boss's skin in the game. New York Times March 21, 2015. Available at: http:// www.nytimes.com/2015/03/22/business/economy/ways-toput-the-bosss-skin-in-the-game.html?_r=0. 
Adapted from Karceski S. The RESTORE trial: What did we learn about multiple sclerosis? Neurology 2014;82:e155-e157.

WHAT IS MULTIPLE SCLEROSIS? Multiple sclerosis (MS) is an inflammatory disease that affects the CNS (the brain and spinal cord). It affects women about twice as often as men. It is usually diagnosed around age 30 .

The cause of MS is unknown. However, there are several clues about how MS begins. For instance, MS occurs more often in people who live in northern latitudes. Some have proposed that northerners are exposed to an infection in childhood. The immune system forms antibodies to the infectious agent (a bacteria or virus)

Later in life, for reasons that are unclear, the antibodies attach to a protein in the myelin coating of the axons. The body becomes confused and begins destroying the much-needed myelin. Without myelin, nerve cell signals travel much more slowly. This results in weakness, numbness, and other neurologic symptoms.

Something in our genes may be responsible for MS. For instance, a person is more likely to get MS if he or she has a first-degree relative (mom, dad, brother, or sister) with MS. Twenty-five percent of identical twins, who have identical genetic makeup, develop MS if their twin has MS. In comparison, only $2 \%$ of fraternal twins, whose genetic makeup is like a brother or sister, develop MS if their twin has MS.

Some genetic research in MS focuses on how our bodies are able to recognize foreign substances. For instance, in organ transplantation, the immune system may see the transplanted organ as "foreign" and "reject" it. Research into the genetics of MS may show how some people's bodies become "confused." This would help us to identify who is more likely to develop illnesses like MS, where the body attacks its own myelin.

HOW MS AFFECTS THE BRAIN Most people think MS is an illness that mostly affects white matter. Studies show that MS affects gray matter as well. When MS affects gray matter, the nerve cells die. Nerve cell death causes a decrease in the volume of the gray matter. A reduction in volume is called atrophy. Years ago, before MRI, an autopsy might show atrophy. Today, MRI can identify atrophy in the living brain. Newer MRIs are able to detect subtle changes even more easily.

If MS primarily affects the white matter, why do nerve cells die? Some scientists believe that an attack on myelin also affects the axon. Some nerve cells cannot live without their axons. When a nerve cell dies due to axonal injury it is called wallerian degeneration.

Others have proposed that MS affects the nerve cell body directly. In other words, the nerve cell body is destroyed first. Which is correct? Is it the axon first, or is an attack on the cell body the beginning of what we call MS? The answer to this question could lead to a cure for this illness.

As MS affects different parts of the brain, neurologic symptoms appear. Depending on the brain region, these symptoms can be weakness, numbness, or changes in vision or balance. Often the symptoms come and go. In between the symptoms, the person may feel fine. This type of MS is called relapsingremitting MS. In other people, the symptoms appear and gradually worsen over time. This is called progressive MS. Some have observed that white matter is more involved in the relapsing-remitting type, while gray matter may be more involved in the progressive form.

More recent literature has made the distinction between these 2 types less clear. Are they separate illnesses? Does one type turn into the other? How do they overlap? The answers to these questions remain unclear.

The treatments for MS are designed to prevent new symptoms, slow or halt the progression of disease, and reverse the injury that has occurred, if possible.

\section{FOR MORE INFORMATION}

Neurology Now ${ }^{\circledR}$

http://journals.lww.com/neurologynow/Pages/Resource-

Central.aspx

Multiple Sclerosis Association of America

http://www.msassociation.org

Multiple Sclerosis Foundation

http://www.msfocus.org

National Multiple Sclerosis Society

http://www.nationalmssociety.org 


\section{Neurology}

\section{Cost of disease-modifying therapies for multiple sclerosis Murray G. Brown \\ Neurology 2015;84;e181-e185 \\ DOI 10.1212/WNL.0000000000001676}

This information is current as of May 25, 2015

\section{Updated Information \& Services}

References

Subspecialty Collections

Permissions \& Licensing

Reprints including high resolution figures, can be found at: http://n.neurology.org/content/84/21/e181.full

This article cites 1 articles, 0 of which you can access for free at: http://n.neurology.org/content/84/21/e181.full\#ref-list-1

This article, along with others on similar topics, appears in the following collection(s):

All Demyelinating disease (CNS)

http://n.neurology.org/cgi/collection/all_demyelinating_disease_cns Multiple sclerosis

http://n.neurology.org/cgi/collection/multiple_sclerosis

Information about reproducing this article in parts (figures,tables) or in its entirety can be found online at:

http://www.neurology.org/about/about_the_journal\#permissions

Information about ordering reprints can be found online:

http://n.neurology.org/subscribers/advertise

Neurology ${ }^{\circledR}$ is the official journal of the American Academy of Neurology. Published continuously since 1951, it is now a weekly with 48 issues per year. Copyright (C 2015 American Academy of Neurology. All rights reserved. Print ISSN: 0028-3878. Online ISSN: 1526-632X.

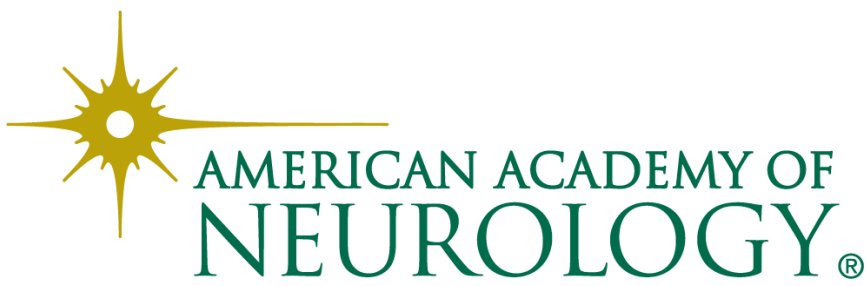

